\title{
Assessment of Heavy Metal Levels in Soil and Vegetables in Some Farms Around Mining Sites in Mangu Local Government Area Plateau State, Nigeria
}

\author{
Nanven D. Nimyel and Elizabeth S. Chundusu
}

\section{ABSTRACT}

\begin{abstract}
When the mining process is not properly controlled, it can be a source of heavy metals pollution in the environment. The uptake of these heavy metals in edible parts of vegetables can be a direct source of the metals into the human food chain. This study assessed the concentrations of lead $(\mathrm{Pb})$, manganese (Mn), zinc $(\mathrm{Zn})$, copper $(\mathrm{Cu})$, nickel $(\mathrm{Ni})$ and chromium $(\mathrm{Cr})$ in soil and vegetables obtained from nine (9) farms around mining sites in Mangu LGA. Concentrations of heavy metals in soil and vegetables were determined using atomic absorption spectrophotometer (AAS). The results revealed the concentrations of the heavy metals at the farms to be within the recommended maximum levels of world soils but were higher than their respective controls. This implies that the artisanal mining contributed to the increased values of these heavy metals in the environment. Also, the mean concentrations of the heavy metals at Mangu Halle mining site decreased in the order $\mathrm{Mn}>\mathrm{Zn}>\mathrm{Cr}>\mathrm{Cu}>\mathrm{Ni}>\mathrm{Pb}>\mathrm{Cd}$ whereas at Alogwom it decreased in the order $\mathrm{Mn}>\mathrm{Zn}>\mathrm{Pb}>\mathrm{Cu}>\mathrm{Ni}>\mathrm{Cr}>\mathrm{Cd}$. The enrichment factor (EF) of the elements showed deficiency to minimum enrichment for all the heavy metals whereas the pollution index (PI) of the metals indicated very slight contamination to moderate pollution. The results of the heavy metals in the vegetables showed that the bioaccumulation of the metals followed a pattern: $\mathrm{Zn}>\mathrm{Cu}>\mathrm{Pb}>\mathrm{Cr}>\mathrm{Cd}>\mathrm{Ni}$. Levels of $\mathrm{Cd}, \mathrm{Pb}$ and $\mathrm{Ni}$ in the vegetables were observed to be higher than the recommended limit for vegetables whereas $\mathrm{Cu}, \mathrm{Cr}$ and $\mathrm{Zn}$ exhibited lower values than recommended standards. Thus, their consumption might pose health risk to consumers and therefore there is the need for proper monitoring of the illegal mining activities to reduce health risk and the extent of heavy metals contamination.
\end{abstract}

Keywords: Assessment, Enrichment factor, Farm, Heavy Metal, Mining, Soil, Vegetable.
Published Online: November 22, 2021

ISSN: $2684-4478$

DOI: $10.24018 /$ ejchem.2021.2.5.81

N. D. Nimyel*

Department of Science, School of Science and Technology, Plateau State Polytechnic, Barkin Ladi, Nigeria.

(e-mail: nimyelnanven ${ }^{\circledR}$ yahoo.com) E. S. Chundusu

Department of Science, School of Science and Technology, Plateau State Polytechnic, Barkin Ladi, Nigeria. (e-mail: Chundusu2001 @ yahoo.com)

*Corresponding Author

\section{INTRODUCTION}

The presence of heavy metals in the environment as a result of both natural and human-induced activities have threaten the qualities of crop produce when present in excess concentrations in farm soils [1]. Other researchers have reported that heavy metals are of environmental concern due to their bioaccumulation in soil and vegetables [2], [3]. Therefore, land contamination is a threat to long-term agricultural development and food security in developing countries [1], [4]. Another concern with illegal mining is the high level of destruction of farmlands. Mafuyai et al. [5] reported that mining generally enriched heavy metals in soil leading to elevated levels in both plants and water samples. They also reported that sometimes the metals are very well preserved for hundreds of years and can remain a potential hazard for the environment. The abandoned ponds and dumps tailing scattered still impact the environment by contaminating vegetables as well as pollution of underground water by discharged leachate [3], [6].

There is increased knowledge about the adverse effects of heavy metals on environmental and human health which has led to closer examination of the presence of such elements in agriculture ecosystems [3], [7]. The presence of heavy metals in the environment is of great concern because they are not biodegradable, have long biological half-lives and have the potential for buildup in the different body organs leading to unwanted side effects [7]-[10]. The use of fertilizers and some pesticides have contributed to the heavy metals in the environment. The heavy metals are sometimes purposefully included as required components or present as naturally occurring contaminants or introduced when waste materials are used to formulate fertilizer products [1], [7]. The bioaccumulation of heavy metals in edible parts of vegetables serves as their 
sources into the human food chain, because vegetables absorb heavy metals from contaminated sources [3], [9], [11], [12]. However, the metal uptake in crops is regulated by several factors, including bioavailability of the metal in soil, crop type and metal distribution in the crop [13]-[15]. This research work therefore seeks to determine the concentrations of heavy metals, cadmium $(\mathrm{Cd})$, nickel $(\mathrm{Ni})$, lead $(\mathrm{Pb})$, zinc $(\mathrm{Zn})$, manganese $(\mathrm{Mn})$, and copper $(\mathrm{Cu})$ in topsoil and vegetables grown around two mining areas of Mangu Local Government Area of Plateau State, Nigeria.

\section{MATERIALS AND METHODS}

\section{A. Description of Study Area}

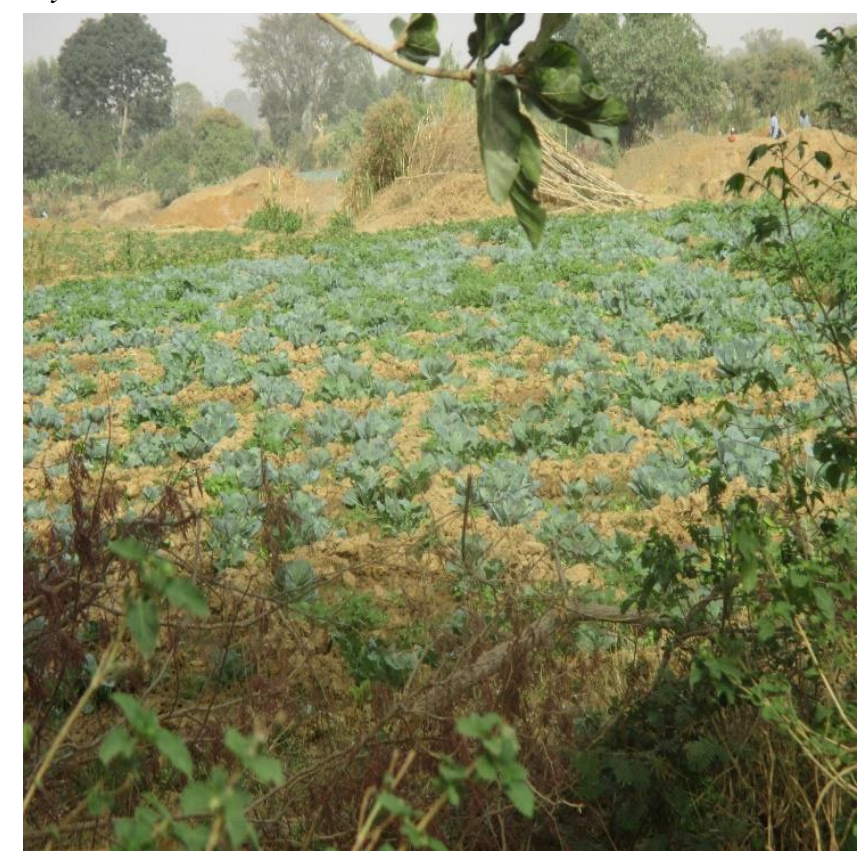

Plate 1. A Farm Cultivated Around Aluvial Deposit and Irrigated with Mining Water Pond at Mangu Halle.

Mangu is a Local Government Area in Plateau State, Nigeria. Its headquarters are in the town of Mangu at $9^{\circ} 31^{\prime} 00^{\prime \prime} \mathrm{N} 9^{\circ} 06^{\prime} 00^{\prime \prime} \mathrm{E}$. It has an area of $1,653 \mathrm{~km}^{2}$ and a population of 294931 at the 2006 census. Artisanal (illegal) mining is still going on in some communities in Mangu at the time of this research leaving behind so many abandoned mining ponds, dams, alluvial deposits, and mining wells scattered all over. Farmers cultivate vegetables on alluvial deposits and irrigate the farms with ponds (see Fig. 1 \& 2).

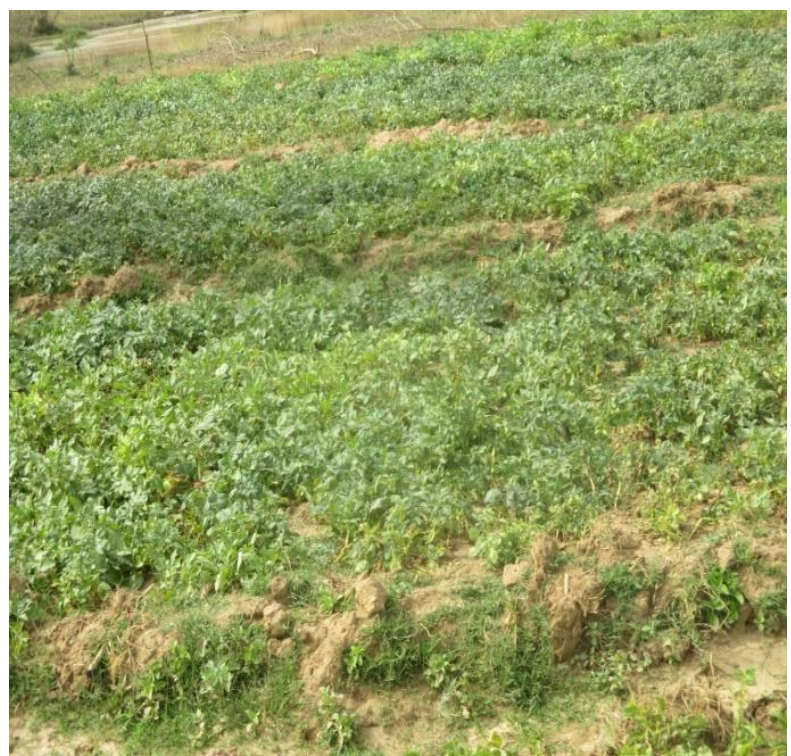

Plate 2. A Farm Cultivated Around Aluvial Deposit and Irrigated with Mining Water Pond at Alogwom. 
European Journal of Advanced Chemistry Research www.ej-chem.org

\section{B. Sample Collection and Preparation}

Topsoil samples were collected randomly from the farmland around the mining sites ( Mangu Halle and Alogwom) using a plastic spoon within the depth of about $1-5 \mathrm{~cm}$ and put in a labeled polyethylene bag. The samples were air dried in the laboratory, ground with mortar and pestle, and then sieved with a $2 \mathrm{~mm}$ mesh. The sieved samples were stored in labeled polyethene bags prior to analysis [14]. Similarly, the vegetable samples were collected randomly in the farmland at the same points where the soil samples were collected using stainless knife. The samples were then put in polyethylene bags and labeled properly. In the laboratory, the harvested vegetables were washed with de-ionized water to remove soil particles and then cut with stainless steel knife and oven dried at $80{ }^{\circ} \mathrm{C}$ until stable weight was obtained [11]. The dried vegetable samples were then ground in a mortar, sieved, and kept for heavy metal analysis.

\section{Analysis of Heavy Metals in Samples}

\section{1) Digestion of the Soil Samples}

One gram $(1.0 \mathrm{~g})$ of the soil sample was digested with $25 \mathrm{ml}$ of aqua regia $\left(\mathrm{HCl}+\mathrm{HNO}_{3}, 3: 1 \mathrm{v} / \mathrm{v}\right)$ at ${ }^{\circ} \mathrm{C}$ on a water bath in a fume cupboard. This process was repeated with another $1.0 \mathrm{~g}$ of the soil sample. The digested samples were filtered into $100 \mathrm{ml}$ volumetric flask each and made up to the mark with distilled/deionised water [16]. The concentrations of the metals in the digested soil sample solutions were determined atomic absorption spectrophotometer (AAS).

\section{2) Digestion of the Vegetable Samples}

One gram ( $1.0 \mathrm{~g}$ ) of vegetable sample was digested with $25 \mathrm{ml}$ aqua-regia and $5 \mathrm{ml}$ of $30 \% \mathrm{H}_{2} \mathrm{O}_{2}$ in a $100 \mathrm{ml}$ pyrex beaker and was digested at $800^{\circ} \mathrm{C}$ on a hot plate until a clear solution was obtained [14], [16]. The whole process was repeated with another fresh sample. After cooling, the digested samples were filtered using Whatman filter paper No.42 and diluted to $50 \mathrm{ml}$ with de-ionized water. The concentrations of the heavy metals in the digested soil sample solutions were determined using Buck Scientific model 210VGP atomic absorption spectrophotometer at wavelengths and slits specific to each metal. The heavy metals analysed were lead $(\mathrm{Pb})$, copper $(\mathrm{Cu})$, nickel $(\mathrm{Ni})$, zinc $(\mathrm{Zn})$, cadmium $(\mathrm{Cd})$ and manganese $(\mathrm{Mn})$.

\section{Statistical Analysis}

The values of means were calculated and two-factor without replication ANOVA was used to ascertain the relationships between the heavy metals in the farms, and vegetables. Enrichment factor (EF) and Pollution index (PI) were also calculated. The enrichment factors of the heavy metals in soil were calculated with the formula:

$$
\mathrm{EF}=\frac{C(\mathrm{M}-\mathrm{S}) / C(M n-S)}{C(\mathrm{M}-\mathrm{C}) / C(M n-C)}
$$

where $C(\mathrm{M}-\mathrm{S})$ is concentration of metal in the sample, $C(M n-S)$ is concentration of reference metal in the sample, $C(\mathrm{M}-\mathrm{C})$ is concentration of metal in the control, $C(M n-C)$ is concentration of reference metal in the control. The control represents a farm far from the mining site. The contamination/pollution index (PI) was calculated as the ratio between metals effectively measured by chemical analysis to the reference value [14], ]17]. The conversion formula for the pollution index was also used and the reference standard used in the calculation was the Federal Environmental Protection Agency target value [18].

\section{RESUlTS AND DISCUSSION}

\section{A. Concentration of Heavy Metals in Farmland Soil}

The concentrations of the heavy metals in the farmland soils at Mangu Halle and Alogwom mining areas are presented in Tables I and II, respectively. From Table I, the average concentration of $\mathrm{Cu}$ was $25.84 \pm 3.52 \mathrm{mg} / \mathrm{kg}$ whereas the concentration of $\mathrm{Cu}$ at Alogwom was $21.87 \pm 5.96 \mathrm{mg} / \mathrm{kg}$ (see Table II). The results showed that there were slight differences found in the concentrations of $\mathrm{Cu}$ in the farms. The results also revealed that the concentrations of $\mathrm{Cu}$ in this study are within the FAO/WHO 2007 maximum recommended maximum limit in agricultural oil but higher than the control. This implied that there could be a slight level of contamination due to the artisanal mining. The concentration of $\mathrm{Cu}$ in this study agrees with the values reported by Mafuyai et al. [3] at Barkin Ladi but is lower than the findings of Kabir et al. [6] around abandoned $\mathrm{Pb}-\mathrm{Zn}$ mines in Yelu, Alkaleri Local Government Area of Bauchi State. The results of the enrichment factors (EF) for $\mathrm{Cu}$ at Mangu Halle and Alogwom as presented in Tables III and IV showed that the enrichment factors $(\mathrm{EF})$ were $<2$ which indicated deficient to minimum enrichment whereas the pollution index (PI) as presented in Tables VII and VIII showed that Cu ranged from 0.4350.897 which indicated moderate contamination to very severe contamination. 


\section{1) Chromium (Cr)}

The concentration of $\mathrm{Cr}$ ranged from $21.34 \pm 0.04 \mathrm{mg} / \mathrm{kg}-56.32 \pm 0.03 \mathrm{mg} / \mathrm{kg}$ with an average of $31.65 \pm 0.04 \mathrm{mg} / \mathrm{kg}$ at Mangu (see Table I) whereas the concentration at Alogwom ranged from $10.35 \pm 0.04 \mathrm{mg} / \mathrm{kg}-13.34 \pm 0.04 \mathrm{mg} / \mathrm{kg}$ with an average of $11.82 \pm 0.03 \mathrm{mg} / \mathrm{kg}$ (see Table II). In this study, the concentration of $\mathrm{Cr}$ at Alogwom agrees with the values reported by Mafuyai et al. [3] at Barkin Ladi. The low value obtained in this study may be attributed to leaching of metals beneath the soil. However, the concentrations at Mangu were higher than the values reported by the same authors but similar to the work of Ghosh et al. [19]. In like manner, the results of Cr reported by Daniel et al. [12] were higher than both farmlands in this study. The results also revealed that the concentrations of $\mathrm{Cr}$ are within the FAO/WHO [20] maximum recommended maximum limit $(150 \mathrm{mg} / \mathrm{kg})$ in agricultural soil but higher than the control. This also showed there could be a slight level of contamination with $\mathrm{Cr}$ as a result of the artisanal mining. Similarly, EF for $\mathrm{Cr}$ at Mangu Halle and Alogwom indicated deficiency to minimum enrichment whereas the pollution index (PI) range of $0.104-0.561$ at the two mining sites also showed moderate contamination to very severe contamination.

\section{2) Manganese (Mn)}

Likewise, from Table I, the concentration of Mn ranged from $224.93 \pm 0.24 \mathrm{mg} / \mathrm{kg}-245.24 \pm 0.16 \mathrm{mg} / \mathrm{kg}$ with an average of $236.09 \pm 5.27 \mathrm{mg} / \mathrm{kg}$ at Mangu whereas the concentration of Mn at Alogwom ranged from $252.61 \pm 0.04 \mathrm{mg} / \mathrm{kg}-264.13 \pm 0.40 \mathrm{mg} / \mathrm{kg}$ with an average of $259.02 \pm 4.14 \mathrm{mg} / \mathrm{kg}$ (see Table II). The results also revealed that there was not a big difference in the concentrations of $\mathrm{Mn}$ at the two mining sites. However, the concentrations of $\mathrm{Mn}$ in the farmlands were higher than in the controls. This could mean that the mining waste contributed to the source of soil contamination. In this study, the concentrations of $\mathrm{Mn}$ at Alogwom and Mangu were higher than the values reported by Mafuyai et al. [3] at Barkin Ladi but were within the range reported by Ali et al. [21]. The concentrations of Mn are within the DPR [18] maximum recommended maximum limit $(850 \mathrm{mg} / \mathrm{kg})$ in agricultural soil. The EF also indicated deficiency to minimum enrichment while the values of pollution index (P/I) indicated severe contamination.

\section{3) Cadmium $(C d)$}

In like manner, the concentration of Cd ranged from $0.33 \pm 0.05 \mathrm{mg} / \mathrm{kg}-0.62 \pm 0.04 \mathrm{mg} / \mathrm{kg}$ with an average of $0.49 \pm 0.04 \mathrm{mg} / \mathrm{kg}$ at Mangu (see Table I) whereas from Table II, the concentration of Cd at Alogwom ranged from $0.44 \pm 0.04 \mathrm{mg} / \mathrm{kg}-0.56 \pm 0.04 \mathrm{mg} / \mathrm{kg}$ with an average of $0.51 \pm 0.05 \mathrm{mg} / \mathrm{kg}$. The concentrations of $\mathrm{Cd}$ at the two mining sites were not too different from one another. The results also revealed the concentrations of $\mathrm{Cd}$ to be lower than the values reported by Baghaie and Aghili [19] in agricultural soils around Nakhlak Pb-Zn mine, located in Anarak district, Nain county of Isfahan province but were within the range reported by Mafuyai et al. [3] at Barkin Ladi. It could also be seen that the concentrations of Cd in this study were within the background values of world soils [20], [23], [24] in agricultural soil but higher than the control. This also indicated that the mining waste could have contributed to the source of soil contamination. The calculated $\mathrm{EF}$ for $\mathrm{Cd}$ also showed deficiency to minimum enrichment whereas PI values showed moderate contamination to very severe contamination.

\section{4) Zinc (Zn)}

The mean concentrations of $\mathrm{Zn}$ at Mangu Halle and Alogwom were $159.77 \pm 13.3 \mathrm{mg} / \mathrm{kg}$ and $157.2 \pm 8.00 \mathrm{mg} / \mathrm{kg}$, respectively. From the results, there were also not big differences in the concentrations of $\mathrm{Zn}$ at the two mining sites. The concentrations of $\mathrm{Zn}$ were within the maximum recommended limit of $300 \mathrm{mg} / \mathrm{kg}$ for $\mathrm{Zn}$ in agricultural soil as prescribed by USEPA and FEPA. However, the concentrations of $\mathrm{Zn}$ were higher than the control. This again indicated that the artisanal mining could have contributed to the source of soil contamination. The concentrations of $\mathrm{Zn}$ in this study were higher than the values reported by other researchers [3], [21], [25]-[27] but within the range reported by Baghaie and Aghili [22] in agricultural soils around Nakhlak $\mathrm{Pb}-\mathrm{Zn}$ mine, located in Anarak district, Nain County. On the other hand, the pollution index of $\mathrm{Zn}$ ranged from very severe contamination to slight pollution.

\section{5) $\operatorname{Nickel}(\mathrm{Ni})$}

The concentration of Ni on the other hand ranged from $2.84 \pm 0.04 \mathrm{mg} / \mathrm{kg}-8.83 \pm 0.06 \mathrm{mg} / \mathrm{kg}$ with an average of $6.19 \pm 0.04 \mathrm{mg} / \mathrm{kg}$ at Mangu (Table I) whereas from Table II, the concentration of $\mathrm{Ni}$ at Alogwom ranged from $10.66 \pm 0.04 \mathrm{mg} / \mathrm{kg}-15.60 \pm 0.15 \mathrm{mg} / \mathrm{kg}$ with an average of $13.06 \pm 0.45 \mathrm{mg} / \mathrm{kg}$. In this study, the concentrations of $\mathrm{Ni}$ at Alogwom and Mangu were lower than the values reported by other researchers [21], [22], [28]. The average concentrations of Ni were within the target value according to WHO standard but higher than the control. This again was an indication that the artisanal mining contributed to the contamination of the soil with $\mathrm{Ni}$. The pollution index for Ni showed very slight contamination to slight contamination (Table III and IV). 


\section{6) $\operatorname{Lead}(\mathrm{Pb})$}

From Table I also, the concentration of $\mathrm{Pb}$ ranged from $0.43 \pm 0.02 \mathrm{mg} / \mathrm{kg}-0.88 \pm 0.06 \mathrm{mg} / \mathrm{kg}$ with an average of $0.71 \pm 0.04 \mathrm{mg} / \mathrm{kg}$ whereas from Table II, the concentration of Pb ranged from $20.43 \pm 0.12 \mathrm{mg} / \mathrm{kg}$ - $24.37 \pm 0.0 \mathrm{mg} / \mathrm{kg}$ with an average of $22.15 \pm 0.45 \mathrm{mg} / \mathrm{kg}$. From the results, the concentrations of $\mathrm{Pb}$ at Alogwom were higher than Mangu. This could be due to the concentration of the metal at the mining sites or the $\mathrm{Pb}$ at Mangu Halle could have been leached during rainy season. The values of $\mathrm{Pb}$ at Mangu Halle and Alogwom were lower than the values reported by Mafuyai et al. [3] and Ako et al. [28] at Minna, Niger State but conformed to the findings of Abiya et al. [27]. The average concentrations of $\mathrm{Pb}$ at both sites were within the target value range of $70-300 \mathrm{mg} / \mathrm{kg}$ according to WHO and USEPA. The values of $\mathrm{Pb}$ at the two sites were higher than the control. This again could be an indication that the artisanal mining contributed to the contamination of the environment with $\mathrm{Pb}$. The EF also indicated deficiency to minimum enrichment except at sample B with value 2.030 which was moderate enrichment. The pollution index values showed that $\mathrm{Pb}$ at all sampling sites had very slight contamination.

Generally, the concentrations of the heavy metals at the farms were within the recommended background values of world soils [23]-[24] but were higher than their respective controls. This could be implied that the artisanal mining contributed to the increased values of these heavy metals in the environment. The mean concentration of the heavy metals at Mangu Halle mining site decreased in the order $\mathrm{Mn}>\mathrm{Zn}>\mathrm{Cr}>\mathrm{Cu}>$ $\mathrm{Ni}>\mathrm{Pb}>\mathrm{Cd}$ whereas the mean values at Alogwom decreased in the order $\mathrm{Mn}>\mathrm{Zn}>\mathrm{Pb}>\mathrm{Cu}>\mathrm{Ni}>\mathrm{Cr}$ $>\mathrm{Cd}$. Generally, the results of EF for the elements showed deficiency to minimum enrichment for all the heavy metals. The PI indicated very slight contamination to moderate pollution.

TABLE I: The CONCENTRATION OF HeAvy Metals in the FARMLAND SOIL AT MANGU HaLlE

\begin{tabular}{cccccccc}
\hline \multicolumn{7}{c}{ Sample Concentration $(\mathrm{mg} / \mathrm{kg})$} \\
\hline $\mathrm{Au}$ & $\mathrm{Cr}$ & $\mathrm{Mn}$ & $\mathrm{Cd}$ & $\mathrm{Zn}$ & $\mathrm{Ni}$ & $\mathrm{Pb}$ \\
\hline $\mathrm{B}$ & $24.20 \pm 0.01$ & $21.34 \pm 0.04$ & $240.11 \pm 0.14$ & $0.62 \pm 0.04$ & $150.5 \pm 0.21$ & $2.84 \pm 0.04$ & $0.81 \pm 0.01$ \\
$\mathrm{C}$ & $32.10 \pm 0.01$ & $45.27 \pm 0.05$ & $224.93 \pm 0.24$ & $0.49 \pm 0.05$ & $163.5 \pm 0.25$ & $4.82 \pm 0.08$ & $0.43 \pm 0.02$ \\
$\mathrm{D}$ & $24.40 \pm 0.01$ & $42.34 \pm 0.02$ & $245.24 \pm 0.16$ & $0.53 \pm 0.07$ & $155.6 \pm 0.24$ & $8.83 \pm 0.06$ & $0.71 \pm 0.04$ \\
$\mathrm{E}$ & $24.20 \pm 0.04$ & $56.32 \pm 0.03$ & $237.01 \pm 0.24$ & $0.49 \pm 0.03$ & $145.56 \pm 0.27$ & $7.65 \pm 0.05$ & $0.73 \pm 0.06$ \\
Ave. & $25.84 \pm 3.52$ & $31.65 \pm 0.04$ & $236.09 \pm 5.27$ & $0.49 \pm 0.04$ & $159.77 \pm 13.3$ & $6.19 \pm 0.04$ & $0.71 \pm 0.04$ \\
Control & $5.30 \pm 0.01$ & $12.15 \pm 0.04$ & $18.11 \pm 0.01$ & $0.11 \pm 0.01$ & $126.0 \pm 0.44$ & $1.12 \pm 0.01$ & $0.25 \pm 0.01$ \\
\hline
\end{tabular}

TABLE II: THE CONCENTRATION OF HeAvy Metals In THE FARMLAND SOIL AT AlOGWOM

\begin{tabular}{|c|c|c|c|c|c|c|c|}
\hline \multicolumn{8}{|c|}{ Sample Concentration $(\mathrm{mg} / \mathrm{kg})$} \\
\hline & $\mathrm{Cd}$ & $\mathrm{Zn}$ & $\mathrm{Cu}$ & $\mathrm{Ni}$ & $\mathrm{Pb}$ & $\mathrm{Mn}$ & $\mathrm{Cr}$ \\
\hline $\mathrm{A}$ & $0.56 \pm 0.04$ & $165.1 \pm 0.04$ & $29.62 \pm 0.04$ & $12.43 \pm 0.04$ & $22.38 \pm 0.04$ & $264.13 \pm 0.04$ & $10.35 \pm 0.04$ \\
\hline B & $0.44 \pm 0.04$ & $156.4 \pm 0.04$ & $15.65 \pm 0.04$ & $10.66 \pm 0.04$ & $20.43 \pm 0.04$ & $260.15 \pm 0.04$ & $11.27 \pm 0.01$ \\
\hline $\mathrm{C}$ & $0.55 \pm 0.04$ & $162.8 \pm 0.04$ & $15.72 \pm 0.04$ & $13.56 \pm 0.04$ & $24.37 \pm 0.04$ & $259.17 \pm 0.04$ & $13.34 \pm 0.04$ \\
\hline $\mathrm{D}$ & $0.49 \pm 0.04$ & $144.5 \pm 0.04$ & $26.48 \pm 0.04$ & $15.60 \pm 0.04$ & $21.47 \pm 0.04$ & $252.61 \pm 0.04$ & $12.33 \pm 0.05$ \\
\hline Av. & $0.51 \pm 0.05$ & $157.2 \pm 8.00$ & $21.87 \pm 5.96$ & $13.06 \pm 0.44$ & $22.15 \pm 0.02$ & $259.02 \pm 4.14$ & $11.82 \pm 0.03$ \\
\hline Control & $0.20 \pm 0.01$ & $86.15 \pm 0.54$ & $8.11 \pm 0.01$ & $5.11 \pm 0.01$ & $6.11 \pm 0.04$ & $35.12 \pm 0.01$ & $1.32 \pm 0.01$ \\
\hline
\end{tabular}

TABLE III: RESULTS OF THE ENRICHMENT FACTORS (EF) OF FARMLAND SOIL AT MANGU HALLE

\begin{tabular}{cccccccc}
\hline Sample & $\mathrm{Cu}$ & $\mathrm{Cr}$ & $\mathrm{Mn}$ & $\mathrm{Cd}$ & $\mathrm{Zn}$ & $\mathrm{Ni}$ & $\mathrm{Pb}$ \\
\hline $\mathrm{A}$ & 0.340 & 0.087 & 1.000 & 0.425 & 0.090 & 0.387 & 0.244 \\
$\mathrm{~B}$ & 0.371 & 0.088 & 1.000 & 0.359 & 0.104 & 0.393 & 0.138 \\
$\mathrm{C}$ & 0.762 & 0.087 & 1.000 & 0.356 & 0.091 & 0.399 & 0.210 \\
$\mathrm{D}$ & 0.350 & 0.086 & 1.000 & 0.340 & 0.088 & 0.303 & 0.273 \\
$\mathrm{E}$ & 0.341 & 0.089 & 1.0000 & 0.233 & 0.113 & 0.392 & 0.218 \\
\hline
\end{tabular}

TABLE IV: RESULTS OF THE ENRICHMENT FACTORS (EF) OF FARMLAND SOIL AT ALOGWOM

\begin{tabular}{cccccccc}
\hline Sample & $\mathrm{Cd}$ & $\mathrm{Zn}$ & $\mathrm{Cu}$ & $\mathrm{Ni}$ & $\mathrm{Pb}$ & $\mathrm{Mn}$ & $\mathrm{Cr}$ \\
\hline $\mathrm{A}$ & 1.431 & 0.980 & 1.868 & 1.244 & 1.767 & 1.000 & 1.160 \\
$\mathrm{~B}$ & 1.141 & 0.943 & 1.002 & 1.084 & 2.030 & 1.000 & 1.138 \\
$\mathrm{C}$ & 1.432 & 0.985 & 1.011 & 1.383 & 1.754 & 1.000 & 0.935 \\
$\mathrm{D}$ & 1.309 & 0.897 & 1.746 & 1.333 & 1.897 & 1.000 & 1.113 \\
\hline
\end{tabular}

TABLE V: POLlution Index (PI) OF FARMLAND AT MANGU HaLle

\begin{tabular}{cccccccc}
\hline Sample & $\mathrm{Cu}$ & $\mathrm{Cr}$ & $\mathrm{Mn}$ & $\mathrm{Cd}$ & $\mathrm{Zn}$ & $\mathrm{Ni}$ & $\mathrm{Pb}$ \\
\hline $\mathrm{A}$ & 0.620 & 0.213 & 0.549 & 0.775 & 1.031 & 0.081 & 0.009 \\
$\mathrm{~B}$ & 0.620 & 0.453 & 0.515 & 0.613 & 1.120 & 0.138 & 0.005 \\
$\mathrm{C}$ & 0.897 & 0.353 & 0.561 & 0.663 & 1.066 & 0.252 & 0.008 \\
$\mathrm{D}$ & 0.677 & 0.423 & 0.542 & 0.613 & 0.997 & 0.219 & 0.009 \\
$\mathrm{E}$ & 0.620 & 0.563 & 0.533 & 0.413 & 1.253 & 0.195 & 0.008 \\
\hline
\end{tabular}

TABLE VI: POLLUTION INDEX (PI) OF FARMLAND SOIL AT ALOGWOM

\begin{tabular}{cccccccc}
\hline Sample & $\mathrm{Cd}$ & $\mathrm{Zn}$ & $\mathrm{Cu}$ & $\mathrm{Ni}$ & $\mathrm{Pb}$ & $\mathrm{Mn}$ & $\mathrm{Cr}$ \\
\hline $\mathrm{A}$ & 0.700 & 1.131 & 0.823 & 0.355 & 0.263 & 0.604 & 0.104 \\
$\mathrm{~B}$ & 0.550 & 1.071 & 0.435 & 0.305 & 0.240 & 0.595 & 0.113 \\
$\mathrm{C}$ & 0.688 & 1.115 & 0.437 & 0.387 & 0.287 & 0.593 & 0.133 \\
$\mathrm{D}$ & 0.613 & 0.990 & 0.736 & 0.446 & 0.253 & 0.578 & 0.123 \\
\hline
\end{tabular}


From Table VII, the statistical analyses of the soil samples showed they were not significantly different, in other words, the soil samples were the same based on the metal concentrations in them. This was because the F- calculated (2.160227) was less than the critical F (2.533555). However, the metal concentrations in the soil samples were not the same because the critical Value (2.420523) was less than the F calculated (38.0155). From Table VIII the analyses of the vegetables also revealed that the metal concentrations were not the same because the critical Value (2.71089) was less than the F calculated (11.39168).

TABLE VII: ANOVA VARIATIONS OF METALS IN SOIL SAMPLES

\begin{tabular}{|c|c|c|c|c|c|c|}
\hline $\begin{array}{l}\text { Source of } \\
\text { Variation }\end{array}$ & SS & df & MS & $\mathrm{F}$ & P-value & F crit \\
\hline $\begin{array}{c}\text { Soil } \\
\text { Sample }\end{array}$ & 11498.58 & 5 & 2299.716 & 2.160227 & 0.085262 & 2.533555 \\
\hline Metals & 242821.3 & 6 & 40470.22 & 38.0155 & 0.000000 & 2.420523 \\
\hline Error & 31937.15 & 30 & 1064.572 & & & \\
\hline Total & 286257 & 41 & & & & \\
\hline \multicolumn{7}{|c|}{ TABLE VIII: ANOVA VARIATIONS OF METALS IN VEGETABLE SAMPLES } \\
\hline $\begin{array}{l}\text { Source of } \\
\text { Variation }\end{array}$ & SS & df & MS & $\mathrm{F}$ & P-value & F crit \\
\hline Vegetables & 159.4695 & 4 & 39.86737 & 2.887359 & 0.048847 & 2.866081 \\
\hline $\begin{array}{l}\text { Metal } \\
\text { Conc }\end{array}$ & 786.456 & 5 & 157.2912 & 11.39168 & 0.000000 & 2.71089 \\
\hline Error & 276.1511 & 20 & 13.80756 & & & \\
\hline Total & 1222.077 & 29 & & & & \\
\hline
\end{tabular}

\section{B. Concentration of Heavy Metals in Vegetables}

The results of the concentrations of heavy metals (lead $(\mathrm{Pb})$, manganese $(\mathrm{Mn})$, zinc $(\mathrm{Zn})$, copper $(\mathrm{Cu})$, nickel (Ni), and chromium (Cr)) in some vegetables obtain from the mining sites (Mangu Halle and Alogwom) are presented in Tables IX and X.

\section{1) $\operatorname{Nickel}(\mathrm{Ni})$}

The results $\mathrm{Ni}$ in the vegetables revealed that the maximum concentration of $\mathrm{Ni}(0.46 \pm 0.01 \mathrm{mg} / \mathrm{kg}) \mathrm{was}$ recorded in cabbage and the lowest concentration of $0.06 \pm 0.01 \mathrm{mg} / \mathrm{kg}$ was recorded in pepper (see Table IX) whereas in Table X, the maximum concentration of Ni was recorded in spinach $(0.66 \pm 0.01 \mathrm{mg} / \mathrm{kg})$ and the lowest concentration of $0.14 \pm 0.02 \mathrm{mg} / \mathrm{kg}$ was recorded in tomato. The results also revealed that the concentrations of $\mathrm{Ni}$ in the vegetables decreased in the order cabbage > onion > spinach > tomato $>$ beans = pepper (see Table IX). On the other hand, at Alogwom, the concentrations of $\mathrm{Ni}$ in the vegetables decreased in the order spinach $>$ scent leaf $>$ turmeric $>$ pepper $>$ tomato (Table X). The concentrations of $\mathrm{Ni}$ in vegetables in this study were lower than the values reported by Shirklanloo et al. [29] and Latiff et al. [30] but in agreement with the values reported by Hussain et al. [31]. However, the concentrations of $\mathrm{Ni}$ in the vegetables were higher than the recommended safe limit of FAO/ WHO $(0.1 \mathrm{mg} / \mathrm{kg})$ except in beans and pepper at Mangu Halle. Nickle is a poisonous heavy metal; therefore, regular consumption of these vegetables may have an adverse effect [32].

\section{2) $\operatorname{Lead}(\mathrm{Pb})$}

The results for the concentrations of $\mathrm{Pb}$ revealed that the maximum concentration of $\mathrm{Pb}$ $(2.82 \pm 0.11 \mathrm{mg} / \mathrm{kg})$ was recorded in onion and the lowest concentration of $0.86 \pm 0.06 \mathrm{mg} / \mathrm{kg}$ was recorded in beans. In a similar development, at Alogwom the maximum value of $1.56 \pm 0.21 \mathrm{mg} / \mathrm{kg}$ was recorded in turmeric and the lowest value of $0.06 \pm 0.01 \mathrm{mg} / \mathrm{kg}$ was recorded in pepper. The concentrations of $\mathrm{Pb}$ in the vegetables at Mangu Halle decreased in the order onion $>$ spinach $>$ cabbage $>$ pepper $>$ tomato $>$ beans (Table VII) while at Alogwom the values decreased in the order spinach $>$ scent leaf $>$ turmeric $>$ pepper $>$ tomato (Table VIII). The concentrations of $\mathrm{Pb}$ in the vegetables were higher than the recommended safe limit of FAO/ WHO $(0.3 \mathrm{mg} / \mathrm{kg})$ except in pepper at Alogwom. Lead $(\mathrm{Pb})$ has been reported to be a serious cumulative body poison which penetrates into the body system via food air and water respectively and cannot be detached by washing the vegetables [29]. It is worth noting that consumption of these vegetables from this studied area as food may constitute possible health hazards to humans at the time of the study [7], [33]. The higher levels of $\mathrm{Pb}$ contamination found in the vegetables could be closely related to the pollutants in irrigation water, farm soil, and pesticides [34]. The concentrations of $\mathrm{Pb}$ in this study are similar to the values reported by Orisakwe et al. [35] at Dilimi, Bukuru and Barkin Ladi but higher than the values reported by Elbargemi et al. [34] and Latiff et al. [30]. However, the concentrations of $\mathrm{Pb}$ in this study is much lower than the values reported by Mallik et al., [35] and Ayejuwo et al. [33] along Nigeria-Republic of Benin border Seme.

\section{3) Chromium $(\mathrm{Cr})$}

Likewise, the maximum concentration of $\mathrm{Cr}$ at Mangu Halle mining site was $1.88 \pm 0.02 \mathrm{mg} / \mathrm{kg}$ which was recorded in pepper and the lowest concentration of $0.19 \pm 0.03 \mathrm{mg} / \mathrm{kg}$ was recorded also in beans (Table 
IX) whereas at Alogwom mining site, the maximum value of $3.31 \pm 0.30 \mathrm{mg} / \mathrm{kg}$ was recorded in scent leaf and the least value of $1.33 \pm 0.27 \mathrm{mg} / \mathrm{kg}$ was recorded in turmeric (Table $\mathrm{X}$ ). The concentrations of $\mathrm{Cr}$ in the vegetables at Mangu decreased in the order pepper $>$ onion $>$ cabbage $>$ tomato $>$ spinach $>$ beans $($ Table IX) while at Alogwom, the order was scent leaf $>$ spinach $>$ pepper $>$ tomato $>$ turmeric (Table $\mathrm{X}$ ).

TABLE IX: THE MEAN CONCENTRATION OF HEAVy METAls In Vegetables GRown AROUND THE MiNing SiTES AT MANGU HALLE

\begin{tabular}{ccccccc}
\multicolumn{7}{c}{ AROUND THE MINING SITES AT MANGU HALLE } \\
\hline \multicolumn{7}{c}{ Vegetables Concentration $(\mathrm{mg} / \mathrm{kg})$} \\
\hline Cabbage & $0.46 \pm 0.01$ & $1.45 \pm 0.03$ & $0.95 \pm 0.01$ & $9.36 \pm 0.15$ & $0.88 \pm 0.01$ & $23.16 \pm 0.14$ \\
Spinach & $0.29 \pm 0.01$ & $1.97 \pm 0.02$ & $0.61 \pm 0.02$ & $7.56 \pm 0.25$ & $1.40 \pm 0.01$ & $21.27 \pm 0.06$ \\
Tomato & $0.22 \pm 0.02$ & $0.98 \pm 0.05$ & $0.69 \pm 0.01$ & $1.63 \pm 0.01$ & $0.64 \pm 0.02$ & $12.48 \pm 0.03$ \\
Pepper & $0.06 \pm 0.01$ & $1.16 \pm 0.03$ & $1.88 \pm 0.02$ & $2.43 \pm 0.04$ & $0.26 \pm 0.01$ & $13.07 \pm 0.11$ \\
Onion & $0.31 \pm 0.02$ & $2.82 \pm 0.11$ & $1.15 \pm 0.01$ & $0.59 \pm 0.01$ & $1.86 \pm 0.04$ & $23.96 \pm 0.12$ \\
Beans & $0.06 \pm 0.03$ & $0.86 \pm 0.06$ & $0.19 \pm 0.03$ & $5.68 \pm 0.22$ & $0.19 \pm 0.01$ & $10.35 \pm 0.03$ \\
\hline
\end{tabular}

TABLE X: The Mean Concentration of HeAvy Metals in Vegetables Grown ARound the Mining Sites at Alogwom

\begin{tabular}{ccccccc}
\hline \multirow{2}{*}{ Vegetable } & \multicolumn{5}{c}{ Concentration $(\mathrm{mg} / \mathrm{kg})$} \\
\cline { 2 - 6 } & $\mathrm{Ni}$ & $\mathrm{Cd}$ & $\mathrm{Cu}$ & $\mathrm{Cr}$ & $\mathrm{Pb}$ & $\mathrm{Zn}$ \\
\hline Scent leaf & $0.25 \pm 0.01$ & $1.28 \pm 0.84$ & $10.64 \pm 0.18$ & $3.31 \pm 0.30$ & $1.44 \pm 0.05$ & $21.84 \pm 0.83$ \\
Turmeric & $0.21 \pm 0.02$ & $0.75 \pm 0.51$ & $0.36 \pm 0.11$ & $1.33 \pm 0.27$ & $1.56 \pm 0.21$ & $12.22 \pm 0.19$ \\
Spinach & $0.66 \pm 0.01$ & $1.17 \pm 0.51$ & $10.79 \pm 0.18$ & $3.00 \pm 0.16$ & $1.35 \pm 0.48$ & $25.65 \pm 0.79$ \\
Tomato & $0.14 \pm 0.02$ & $0.80 \pm 0.05$ & $0.93 \pm 0.01$ & $1.66 \pm 0.01$ & $0.74 \pm 0.02$ & $12.08 \pm 0.03$ \\
Pepper & $0.16 \pm 0.03$ & $0.16 \pm 0.03$ & $1.78 \pm 0.02$ & $2.03 \pm 0.04$ & $0.06 \pm 0.01$ & $3.17 \pm 0.11$ \\
\hline
\end{tabular}

Generally, the chromium concentrations in the vegetables were below the WHO / FAO stipulated limit of $5.0 \mathrm{mg} / \mathrm{kg}$. The study revealed that $\mathrm{Cr}$ level in the various vegetables might not pose health risk to consumers. Chromium is crucial for insulin activity and deoxyribonucleic acid transcription in living organisms particularly human beings [40]. The concentrations of $\mathrm{Cr}$ in this study are similar to the values reported by Ametepey et al. [41] but lower than the values reported by Latiff et al. [34]. On the other hand, the concentrations of $\mathrm{Cr}$ in this study are higher than the values reported by Hussain et al. [35].

\section{4) Copper $(\mathrm{Cu})$}

In a similar development, from Table VII, the maximum concentration of $\mathrm{Cu}$ was $9.36 \pm 0.15 \mathrm{mg} / \mathrm{kg}$ which was recorded in cabbage and the lowest concentration of $0.59 \pm 0.01 \mathrm{mg} / \mathrm{kg}$ was recorded also in onions. On the other hand, from Table VIII, the maximum concentration of $10.79 \pm 0.18 \mathrm{mg} / \mathrm{kg}$ was recorded in spinach, and the lowest concentration of $0.36 \pm 0.11 \mathrm{mg} / \mathrm{kg}$ was recorded also in turmeric. The concentrations of $\mathrm{Cu}$ in the vegetables at Mangu Halle mining site decreased in the order cabbage > spinach $>$ beans $>$ pepper $>$ tomato $>$ onions while the order at Alogwom was spinach $>$ scent leaf $>$ pepper $>$ tomato $>$ turmeric (Table VIII). Generally, the concentrations $\mathrm{Cu}$ in the vegetables were also below the WHO / FAO stipulated limit of $73.0 \mathrm{mg} / \mathrm{kg}$. The little concentration of $\mathrm{Cu}$ recorded in this study might be due to the presence of copper in minerals which can be released only by very slow disintegration processes [27], [39]. The concentrations of $\mathrm{Cu}$ in this study are similar to the report of Rapheal and Adebayo [42] but lower than the values reported by Latiff et al. [30]. Latiff et al. [30] also reported $\mathrm{Cu}$ is an essential micronutrient that functions as a biocatalyst, required for body pigmentation. However, most plants contain the amount of $\mathrm{Cu}$ which is insufficient for ordinary development which is typically guaranteed through artificial or organic fertilizers.

\section{5) Cadmium $(C d)$}

Likewise, from Table VII, the maximum concentration of Cd was $1.86 \pm 0.04 \mathrm{mg} / \mathrm{kg}$ which was recorded in onions and the lowest concentration of $0.19 \pm 0.01 \mathrm{mg} / \mathrm{kg}$ was recorded in beans while from Table VIII, the maximum value of $\mathrm{Cd}$ was $1.28 \pm 0.84 \mathrm{mg} / \mathrm{kg}$ recorded in scent leaf and the lowest value was $0.16 \pm 0.03 \mathrm{mg} / \mathrm{kg}$. The concentration of $\mathrm{Cd}$ in the vegetables varied significantly with the leafy vegetables having higher values. Leafy vegetables have been linked with high absorption rates because of their large surface area [30]. Generally, the concentrations Cd in the vegetables were higher than the WHO / FAO [20] stipulated limit of $0.02 \mathrm{mg} / \mathrm{kg}$. Hence showing that the vegetables would be dangerous for human beings consumption. Element like $\mathrm{Cd}$, is non-essential and has no advantageous part in plants, animals and people and has no nutritious capacity, as they are exceptionally toxic [30]. The concentrations of $\mathrm{Cd}$ in the vegetables at Mangu Halle decreased in the order onions $>$ spinach $>$ cabbage $>$ tomato $>$ pepper $>$ bean (Table VII) while the concentration at Alogwom decreased in the order scent leaf $>$ spinach $>$ tomato $>$ turmeric > bean (Table $\mathrm{X}$ ). The concentrations of $\mathrm{Cd}$ in this study are similar to the values reported by Latiff et al. [30] and Odai et al. [34] who reported high cadmium levels that ranged from 0.68 to 1.78 $\mathrm{mg} / \mathrm{kg}$. However, the study conducted by Ametepey et al. [38] showed lower concentrations of Cd in the vegetables studied. Boamponsem et al. [40] reported that $\mathrm{Cd}$ and $\mathrm{Zn}$ may influence each other in plant uptake and accumulation, but they play quite different roles in plant metabolism. They, therefore, asserted that generally $\mathrm{Zn}$ status in the soil and plant plays an important role in $\mathrm{Cd}$ accumulation in crop plants. 


\section{6) Zinc (Zn)}

In a related development, the $\mathrm{Zn}$ concentration in cabbage, spinach, bean, pepper, tomato, scent leaf, turmeric, and onion are presented in Tables 7 and 8. From the results, the maximum concentration of $\mathrm{Zn}$ at Mangu was $23.96 \pm 0.12 \mathrm{mg} / \mathrm{kg}$ which was recorded in onion and the lowest concentration of $10.35 \pm 0.03 \mathrm{mg} / \mathrm{kg}$ was recorded in beans (Table VII). On the other hand, the maximum concentration of Zn at Alogwom was $25.65 \pm 0.79$ recorded in spinach and the lowest concentration of $3.17 \pm 0.11$ was recorded in pepper (Table VIII). The concentrations of $\mathrm{Zn}$ in the vegetables decreased in the order onion > cabbage $>$ spinach > pepper > tomato > beans (Table VII) whereas in Table VIII, the concentrations decreased in the order spinach > scent leaf > turmeric > tomato > pepper. The concentrations of $\mathrm{Zn}$ in this study are in agreement with the report of Mallik et al. [36] but much higher than the values reported by other researchers [27], [31], [41]. However, the concentrations of $\mathrm{Zn}$ in the vegetables were below the WHO / FAO stipulated limit of $60.0 \mathrm{mg} / \mathrm{kg}$ and FEPA stimulated limit of $99.0 \mathrm{mg} / \mathrm{kg}$. In this study, $\mathrm{Zn}$ was found in all the vegetables. As reported by Latiff et al. [30] regular consumption of these vegetables may assist in preventing the adverse effect of $\mathrm{Zn}$ deficiency which results in retarded growth and delayed sexual maturation because of its role in nucleic acid metabolism and protein synthesis.

In this study, the levels of cadmium, lead and nickel in the vegetables were observed to be higher than the recommended limit for vegetables while copper, chromium and zinc exhibited lower values than recommended standards. The results also reveals that the bioaccumulation pattern of heavy metals in this study indicates the trend $\mathrm{Zn}>\mathrm{Cu}>\mathrm{Pb}>\mathrm{Cr}>\mathrm{Cd}>\mathrm{Ni}$ irrespective of the study areas; Mangu Halle and Alogwom mining sites. The variation in the concentration of metals in these vegetables depends on the absorption capacity for each metal by the plant. It is affected by various factors like environmental conditions, human interference, and the nature of the plant [31].

\section{CONCLUSION}

From the results in this study, it could be concluded that the farms were contaminated with heavy metals even though the concentrations were within the recommended background values for agricultural soils. This implies that the artisanal mining has not contributed much to the increased values of these heavy metals in the environment. Generally, the results of EF for the elements showed deficiency to minimum enrichment for all the heavy metals. The PI indicated very slight contamination to moderate pollution. From the results of the concentrations in the vegetables, it could also be concluded that the consumption of these vegetables could be sources of these metals in the food chain especially $\mathrm{Cd}, \mathrm{Pb}$, and $\mathrm{Ni}$ which had values higher than the recommended limit in vegetables.

\section{ACKNOWLEDGEMENT}

The authors are very grateful to Tertiary Education Trust Fund (TETFUND) for sponsoring the research. The authors are grateful to the Laboratory Technologist and Management of the Plateau State Polytechnic, Barkin Ladi.

\section{COMPETING INTERESTS}

This research work was sponsored by Tertiary Education Trust Fund (TETFund), the authors hereby declare that no competing interests exist.

\section{REFERENCES}

[1] J. Abah, P. Mashebe, S.T. Ubwa, and D.D. Denuga. Some heavy metals content of cabbage and soil cultivated in the Bezi Bar farm area of Katima Mulilo, Namibia. American Journal of Chemistry, vol. 4, no. 3, pp. 101-108, 2014.

[2] S. Khan, S. Rehman, A.Z. Khan, M. A. Khan, and M.T. Shah. Soil and vegetables enrichment with heavy metals from geological sources in Gilgit, northern Pakistan. Ecotoxicology and Environmental Safety, vol. 73, pp. 820-1827, 2010. Available at: https://doi.org/10.1016/j.ecoenv.2010.08.016.

[3] G. M. Mafuyai, I. S. Eneji, R. Sha'Ato. Concentration of heavy metals in respirable dust in Jos metropolitan area, Nigeria. Open Journal of Air Pollution, vol.3, pp.10-19, 2014. Available at: https://doi.org/10.4236/ojap.2014.31002.

[4] J. Abah, V.O. Ogugbuaja, and M. A. Geidam. Effect of chemical fertilizers on the levels of some Anions in some cereals grown in Benue State, Nigeria. Proceedings of the 43rd Annual conference of the agricultural society of Nigeria, Abuja, pp. 879-883, 2009.

[5] G. M. Mafuyai, I. S. Eneji, R. Sha'Ato, and L.A. Nnamonu. Heavy metals in soil and vegetables irrigated with ex- tin mining ponds water in Barkin-Ladi Local Government Area Plateau State, Nigeria. Agriculture and Food Sciences Research, vol. 6, no. 2, pp. 211-220, 2019.

[6] S. A. Kabir, M.S. Hassan, M.A. Abbas, and A. M. Kura. Assessment of heavy metals contamination of soil and water around abandoned $\mathrm{Pb}-\mathrm{Zn}$ mines in Yelu, Alkaleri Local Government Area of Bauchi State, Nigeria. International Research Journal of Public and Environmental Health, vol. 4, pp. 72-77, 2017. 
[7] R. Kooner, B.V.C. Mahajan, and W.S. Dhillon. Heavy metal contamination in vegetables, fruits, soil and water - A Critical Review. International Journal of Agriculture, Environment \& Biotechnology, vol. 7, no. 3, pp. 603-612, 2014.

[8] E. Bazrafshan, L. Mohammadi, A. Ansari-Moghaddam, and A. H. Mahvi. Heavy metals removal from aqueous environments by electrocoagulation process- A Systematic Review. Journal Environmental Health Science Engineering, vo. 13, no. 74, pp. $1-16$.

[9] M.U. Henry, R. A. Ogenyi, U.I. Henry, and O. Dogun. Assessment of heavy metal concentration in water, soil and vegetable in ex-mining pond, Jos South L.G.A Plateau State, Nigeria. International Journal of Scientific and Research Publications, vol. 8, pp. 840-845, 2018. Available at: https://doi.org/10.29322/ijsrp.8.8.2018.p80107.

[10] A.M. Shibdawa, S. Lubis, H. Adamu, and S.I. Ibejekwe. Determination of heavy metals concentration in soils used for cultivation of vegetables in Dorowa Mining Areas of Barkin Ladi, Plateau State, Nigeria. ATBU, Journal of Science, Technology \& Education (JOSTE), vol. 7, no. 1, pp. 301-309, 2019.

[11] T. M. Chiroma, R.O. Ebewele, and F.K. Hymore. Comparative assessment of heavy metal levels in soil, vegetables and urban grey waste water used for irrigation in Yola and Kano. International Refereed Journal of Engineering and Science (IRJES), vol. 3, no. 2, pp. 01-09.

[12] V.N. Daniel, E.S. Cundusu, J.A. Chup, and N.D. Pius. Variation of heavy metals in agricultural soil irrigated with tin mining water in Heipang District of Barkin Ladi, plateau State Nigeria. International Journal of Science and Technology vol. 3, no. 5, pp. 225-263, 2014.

[13] M. Tom, T.D. Fletcher, and D.T. McCarthy. Heavy metal contamination of vegetables irrigated by urban storm water: A Matter of Time? PLOS ONE vol. 9, no. 11, pp. 1-21, 2014. doi:10.1371/journal.pone.0112441.

[14] N.D. Nimyel, J.N. Egila, and Y.N. Lohdip. Heavy metal concentrations in some vegetables grown in a farm treated with urban solid waste in Kuru Jantar. Nigeria. British Journal of Applied Science \& Technology, vol. 8, no. 2, pp. 139-147, 2015.

[15] J. J. Steffana, E. C. Brevika, L.C. Burgess, A. Cerda. The Effect of Soil on Human Health: An Overview. Eur. Journal of Soil Science, vol. 69, pp. 159-171, 2018.

[16] C. E. Enyoh, and B. O. Isiuku. Determination and human health risk assessment of heavy metals in flood basin soils in Owerri, Southeastern Nigeria. Chemistry Africa, vol. 3, no. 4, pp. 1059-1071, 2020.

[17] N.A. Obasi, E.I. Akubugwo, O.C. Ugbogu, and G. Otuchristian. Assessment of physico-chemical properties and heavy metals bioavailability in dumpsites along Enugu-Port Harcourt Expressways, South-east, Nigeria. Asian Journal of Applied Sciences, vol. 5, pp. 342-356, 2012.

[18] Department of Petroleum Resource (DPR), "Environmental guidelines and Standard Petroleum Industries in Nigeria: Ministry of Petroleum Resources, Abuja, Nigeria: Ministry of Petroleum Resource, 2002.

[19] A. K. Ghosh, M. Bhatt, and H. Agrawal. Effect of long-term application of treated sewage water on heavy metal accumulation in vegetables grown in Northern India. Environmental Monitoring and Sssessment, vol. 184, pp. 1025-1036, 2012. Available at: https://doi.org/10.1007/s10661-011-2018-6.

[20] WHO/FAO. Joint FAO/WHO food standard programme codex alimentarius commission 13th session. Report of the Thirty Eight Session of the Codex Committee on Food, 2007.

[21] M. Ali, A. Elhagwa, J. Elfaki, and M. Sulieman. Influence of the artisanal gold mining on soilcontamination with heavy metals: A case study from Dar-mali locality, North of Atbara, River Nile, Sudan. Eurasian Journal of Soil Sciences, vol. 6, no. 1, pp. 28-36, 2017.

[22] A. H. Baghaie, and F. Aghili. Investigation of heavy metals concentration in soil around a Pb-Zn mine and ecological risk assessment. Environmental Health Engineering and Management Journal, vol. 6, no. 3, pp. 151-156, 2019.

[23] USEPA. Risk-based concentration table. Washington, DC: United State Environmental Protection Agency, 2010.

[24] Federal Environmental Protection Agency (FEPA). Guidelines and Standards for Environmental Pollution Control in Nigeria, 2010.

[25] A. Mahmood, and R. N. Malik. Human health risk assessment of heavy metals via consumption of contaminated vegetables collected from different irrigation sources in Lahore, Pakistan. Arabian Journal of Chemistry, vol. 7, pp. 91-99, 2014. Available at: https://doi.org/10.1016/j.arabjc.2013.07.002.

[26] A. Ratul, M. Hassan, M. Uddin, M. Sultana, M. Akbor, and M. Ahsan. Potential health risk of heavy metals accumulation in vegetables irrigated with polluted river water. International Food Research Journal, vol. 25, pp. 329-338, 2018.

[27] S.E. Abiya, B.O. Odiyi, F.A. Ologundudu, O.J. Akinnifesi, and S. Akadiri. Assessment of heavy metal pollution in a gold mining site in Southwestern Nigeria. Biomedical Journal of Scientific \& Technical Research (BJSTR), vol. 12, no. 4, pp. 9353-9357, 2019.

[28] T.A. Ako, U.S. Onoduku, S. A. Oke, I.A. Adamu, S.E. Ali, A. Mamodu, and A.T. Ibrahim. Environmental Impact of Artisanal Gold Mining in Luku, Minna, Niger State, North Central Nigeria. Journal of Geosciences and Geomatics, vol. 2, no. 1, pp. 2837,2014

[29] H. Shirkhanloo, N. Shirkhanloo, S.A. Moussavinajarkola, and H. Farahani. The evaluation and determination of heavy metals pollution in edible vegetables, water and soil in the south of Tehran province by GIS. Archives of Environmental Protection, vol. 41, pp. 64-74, 2015.

[30] A. Latif, M. Bilal, W. Asghar, M. Azeem and M.I. Ahmad. Heavy metal accumulation in vegetables and assessment of their potential health risk. Journal of Environmental Analytical Chemistry 5: 234. doi:10.4172/2380-2391.1000234, 2018.

[31] A. Hussain, M. Priyadarshi and S. Dubey. Experimental study on accumulation of heavy metals in vegetables irrigated with treated wastewater. Applied Water Science, vol. 9 no. 122, pp. 1-11, 2019.

[32] G. Genchi, A. Carocci, G. Lauria, M.S. Sinicropi, A. Catalano. Nickel: Human Health and Environmental Toxicology. Int J Environ Res Public Health. 2020, vol. 17, no. 3, pp. 679-685.

[33] O.O. Ayejuyo, M.O. Osundiya, R. A. Olowu, O.A. Bamgboye, and A.O. Ogunlola. Bioaccumulation of heavy metals in frequently consumed leafy vegetable grown along Nigeria-Benin Seme Border. West Africa. Advances in Applied Science Research, vol. 5, no. 1, pp. 1-7, 2014.

[34] M.A. Elbagermi, H.G.M. Edwards, and A.I. Alajta. Monitoring of heavy metal content in fruits and vegetables collected from production and market sites in the Misurata Area of Libya. ISRN Analytical Chemistry, 2012, pp. 1-6, 2012.

[35] O.E. Orisakwe, E.A. Dagur, H.C Mbagwu, and N.A. Udowelle. Lead levels in vegetables from artisanal mining sites of Dilimi River, Bukuru and Barkin Ladi North Central Nigeria: Cancer and Non-Cancer Risk Assessment. Asian Pacific Journal of Cancer Prevention, vol. 18, no. 3, pp. 621-627, 2017.

[36] J. Mallik, J. Dutta, P. Sultana, and A. Mitra. Bioaccumulation pattern of heavy metals in vegetables collected from selected areas in and around Kolkata city (India). International Journal of Higher Education and Research, vol. 7 no. 2, pp. 121-134, 2017.

[37] S.N. Odai, E. Mensah, D. Sipitey, S. Ryo, and E. Awauah. Heavy metals uptake by vegetables cultivated on urban waste dumpsites: case study of Kumasi, Ghana. Res J Environ Toxicol., vol. 2, no. 2, pp. 92-9 2008

[38] S.T. Ametepey, S.J. Cobbina, F.J. Akpabey, A.B. Duwiejuah, and Z.N. Abuntori. Health risk assessment and heavy metal contamination levels in vegetables from Tamale Metropolis, Ghana. International Journal of Food Contamination, vol. 5, no. 5, pp. 1-8, 2018.

[39] C. Radulescu, L. Stihik, A. Barbesk, and E.D. Chilian. Studies concerning heavy metals accumulation of Carduus nutans L. and Taraxacum officinale as potential soil bioindicator species. Revista de Chimie, vol. 64, no. 7, pp. 212-250, 2014. 
[40] O. Rapheal, and K.S. Adebayo. Assessment of trace heavy metal contaminations of some selected vegetables irrigated with water from River Benue within Makurdi Metropolis, Benue State Nigeria. Advances in Applied Science Research vol. 2, pp. 590-601, 2011.

[41] G.A. Boamponsem, M. Kumi, and I. Debrah. Heavy metals accumulation in cabbage, lettuce and carrot irrigated with wastewater from Nagodi mining site in Ghana. International Journal of Scientific \& Technology Research, vol.1, no. 11, pp. 124-129, 2012. 